\title{
Optimization of Gluten-Free Cake Formulations Special to Celiac Patients Using Different Types and Amount of Gluten-Free Flours
}

\author{
Halime Pehlivanoglu ${ }^{1}$, Ervanur Karasu ${ }^{2}$, Esra Nur Yasa ${ }^{2}$, Kubra Gokduman², Hamide Feyza Bardakci ${ }^{2}$ Mehmet $^{2}$ \\ Demirci $^{2 *}$

\footnotetext{
${ }^{1}$ Namık Kemal University, Veterinary Faculty, Food Hygiene and Technology, Tekirdağ/TURKEY, (ORCID: 0000-0003-3138-9568), hpehlivanoglu@nku.edu.tr

2 Istanbul Sabahattin Zaim University, Department of Food Engineering, Istanbul/Turkey, ervakarasuu @ gmail.com

${ }^{2}$ Istanbul Sabahattin Zaim University, Department of Food Engineering, Istanbul/Turkey, esranuryasa@ hotmail.com

${ }^{2}$ Istanbul Sabahattin Zaim University, Department of Food Engineering, Istanbul/Turkey, kbragkdmn@ gmail.com

2 Istanbul Sabahattin Zaim University, Department of Food Engineering, Istanbul/Turkey, feyzabardakci@ gmail.com

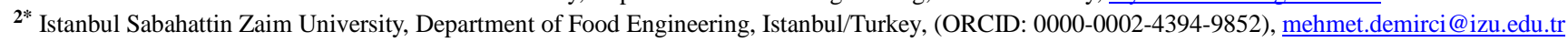

(First received 15 September 2021 and in final form 30 November 2021)

(DOI: $10.31590 /$ ejosat.994986)

ATIF/REFERENCE: Pehlivanoğlu, H., Karasu, E., Yasa, E. N., Gokduman, K., Bardakci, H. F. \& Demirci, M. (2021). Optimization of Gluten-Free Cake Formulations Special to Celiac Patients Using Different Types and Amount of Gluten-Free Flours. European Journal of Science and Technology, (27), 849-857.

\begin{abstract}
The present study aimed to produce gluten-free salty cakes for celiac patience and enhance their functionality by using different nutritionally rich flours. For this purpose, ten different cake formulations were prepared using gluten-free flours, including buckwheat, rice, corn, chickpea, and quinoa flour either as alone or mixture. Physicochemical properties of doughs and final products were analyzed and compared to the control. While viscosity, density, $\mathrm{pH}$, and rheological analysis were conducted in dough samples, color, textural and sensory properties, and mass, volume, baking loss, ash, and moisture analysis were performed in the cakes. Corn cake was found to be the closest sample to control in many sensorial properties, rice cake was found to be the closest in interior color parameters. Regarding dough analysis, the viscosity of chickpea was found to be higher than those of other samples. While the volume of corn dough was the highest, weight was found to be the highest in mixture 1 sample. G' and G" values of quinoa dough were the highest.
\end{abstract}

Keywords: celiac disease, salty cake, gluten-free, functional foods.

\section{Farklı Tip ve Miktarda Glutensiz Un Kullanılarak Çölyak Hastalarına Özel Glutensiz Kek Formülasyonlarının Optimizasyonu} Öz

Bu çalışmada çölyak hastalarına özel glutensiz tuzlu keklerin üretilmesi ve hamur üretiminde besleyici özelliği yüksek farklı glutensiz unlar ile de fonksiyonelliği artırmak amaçlanmıştır. Bu amaçla, karabuğday, pirinç, mısır, nohut ve kinoa unları tek başına ya da karışım olarak kullanılarak on farklı kek formülasyonu hazırlanmıştır. Hamur ve son ürünün fizikokimyasal özellikleri belirlenerek control ile kıyaslanmıştır. Hamurlarda viskozite, yoğunluk, pH ve reolojik analizler yapılırken, keklerde renk, dokusal ve duyusal özellikler ile kütle, hacim, pişme kaybı, kül ve nem analizleri yapılmıştır. Mısır unu içeren kek birçok duyusal özellikte kontrole en yakın örnek olurken, pirinç keki ise iç renk parametrelerinde kontole en yakın örnek olarak bulunmuştur. Hamurlarda yapılan analizlerde nohutun viskozitesi diğer numunelere göre daha yüksek bulunmuştur. Mısır unu hamurunun hacmi en yüksek iken, ağırlık en yüksek karışım 1 örneğinde bulunmuştur. En yüksek G' ve G" değerleri kinoa hamurunda ölçülmüştür.

Anahtar Kelimeler: Çölyak, tuzlu kek, glutensiz, fonksiyonel gidalar.

\footnotetext{
*Corresponding Author: mehmet.demirci@izu.edu.tr
} 


\section{Introduction}

Celiac disease is one of the most common (0.5-1\% of the general population) autoimmune diseases caused by gliadin and similar prolamins present in gluten abundant in wheat, rye, and barley (Radlović, 2013; Caio et al., 2019). The significant finding in the diagnosis of celiac is gluten-sensitive enteropathy, which can be explained as the inflammation of the small intestines (Macho et al., 2020). This inflammation destroys the small intestine mucosa and causes malabsorption of essential nutrients, including fat-soluble vitamins, folic acid, calcium, and iron (Arslan et al., 2019). The only way to inhibit celiac disease is a lifelong gluten-free diet (Norouzbeigi et al., 2020).

Gluten is an alcohol-soluble protein found in grains such as wheat, barley, rye, etc. (Palabıyık et al., 2016; Caio et al., 2019). Gluten mainly consists of soluble monomeric gliadins and insoluble glutenins. In the dough structure, while the gliadin is responsible for the viscous behavior, glutenin is responsible for the elastic behavior (Tang et al., 2019). Cakes are one of the most consumed bakery products all over the world. Wheat flour is one of the main ingredients of cake dough (Pehlivanoğlu et al., 2018).

With the increasing demand for the gluten-free lifestyle (Yildiz et al., 2017), manufacturers focused on producing different gluten-free bakery products using gluten-free flours, starches, hydrocolloids, gums, emulsifiers, etc. (Bourekoua et al., 2016). Gluten-free sources for gluten-free bakery products include buckwheat, rice, quinoa, corn, chickpea, etc. These grains are gluten-free and rich in nutritional components (Moreno et al., 2014).

In the present study, cakes were produced for celiac patients using gluten-free buckwheat, rice, corn, chickpea, and quinoa flours either by each one or by mixing them in different amounts. The purpose was to make the cake having the most desirable properties by comparing the dough formulations prepared and the final product made with these formulations with the reference dough formulations and cake samples.

\section{Material and Method}

\subsection{Material}

Buckwheat, rice, corn, chickpea, quinoa flours, and wheat flour (WF) as the controlling flour used in the cake formulations were provided from the local market by verifying their ingredients. Emulsifiers, citric acid anhydride, demineralized whey powder (DWP), sodium bicarbonate, sodium acid pyrophosphate (SAPP 28), cake fat, eggs, fat-free milk powder, fructose syrup, water, salt, and sugar were supplied by Elvan Food Industry and Trade Inc.

Cake Formulations: Flour type and percentage used in cake production were given in Table 1 .

\subsection{Methods}

\subsubsection{Production of Cakes}

Dough composistion was $35 \%$ flour mix, $1 \%$ emulsifier, $0.04 \%$ citric acid anhydride, $0.5 \%$ DPST, $0.18 \%$ sodium bicarbonate, $0.24 \%$ SAPP, $20 \%$ cake fat, $23 \%$ egg, $0,5 \%$ skimmed milk powder, $1,6 \%$ fructose syrup, $9 \%$ water, $1.2 \%$ salt, $5,3 \%$ sugar. Sugar and eggs were mixed in the highest speed e-ISSN: 2148-2683 for 35-40 seconds. Water, skim milk powder, emulsifier, oil, fructose syrup and citric acid anhydrate were added and mixed for 2 minutes at maximum speed. After that, flour, salt, sodium bicarbonate, SAPP, DPST were added and mixed for 2 minutes at maximum speed. Cake baking molds were greased with spray oil, placed at 40 grams per whole. All samples were prepared in the same procedure, then baked in the preheated oven at $170^{\circ} \mathrm{C}$ for 6 min with fan, at $160{ }^{\circ} \mathrm{C}$ with no fan for $6 \mathrm{~min}$ twice.

\subsubsection{Protein content of flour samples}

AACC 46-10 Kjeldahl method was used for protein analysis (AOAC 2000, methods 992.23). A Behr brand with 53005 (Ukraine) model number Semi-Automatic Kjeldahl Distillation Unit was used. Flour samples around $1 \mathrm{~g}$ were weighed and put into the digestion flask. A catalyst tablet and $25 \mathrm{ml} \mathrm{H} 2 \mathrm{SO} 4$ were added to each tube. The burning process was performed for 30 minutes after the color turned light green and the tubes were left to cool down. $25 \mathrm{ml} 4 \%$ boric acid solution and 5-6 drops of indicator solution were added into $250 \mathrm{ml}$ Erlenmeyer. Then, the distillation process was started. After distillation, samples were titrated with $0,1 \mathrm{~N} \mathrm{HCl}$ solution.

\subsubsection{Analysis Applied to Doughs}

\subsubsection{Viscosity}

The viscosity analysis of the dough was conducted by Brookfield DVII Viscometer (USA). The study was performed by adjusting the heating and cooling cycles of the device. After being kept at $50{ }^{\circ} \mathrm{C}$ for a minute, the temperature was raised to $95^{\circ} \mathrm{C}$ in 3 and a half minutes, and samples were held at this temperature for two and a half minutes. Then, it was cooled down to $50{ }^{\circ} \mathrm{C}$ in 3 and a half minutes and kept at this temperature for 2 minutes (Sakiyanet al., 2009).

\subsubsection{Density}

The density measurements of the cake mixture were calculated by determining the weight of the dough formulations and by dividing the weight of the dough with the weight of the water in the same container ( $1 \mathrm{~g}$ water $=1 \mathrm{ml}$ water).

\subsubsection{Rheological Properties}

Before frequency sweep tests, an amplitude sweep test was performed in the range of 0.1 and $100 \%$ strain to determine the linear viscoelastic region. $0.03 \%$ was the strain value used in frequency sweep tests. Angular velocity values for the frequency sweep tests were between 0.628 and $62.8 \mathrm{rad} / \mathrm{s}$. Regarding viscoelastic values, storage modulus ( $\left.G^{\prime}\right)$, loss modulus ( $\left.G^{\prime \prime}\right)$, complex modulus $\left(\mathrm{G}^{*}\right)$, complex viscosity $\left(\eta^{*}\right)$ and tan $\delta$ were calculated using the following equations (Rao and Cooley, 1992; Yoo and Rao, 1996).

$$
\begin{aligned}
& \mathrm{G}^{\prime}=\mathrm{K}^{\prime} \omega \mathrm{n}^{\prime} \\
& \mathrm{G}^{\prime \prime}=\mathrm{K}^{\prime \prime} \omega \mathrm{n}^{\prime \prime} \\
& \eta^{*}=\mathrm{K}^{*} \omega \mathrm{n}^{*-1}
\end{aligned}
$$

\section{pH Determination}

$\mathrm{pH}$ determination of the dough formulations was conducted by a calibrated $\mathrm{pH}$ meter (Testo hand-held, Germany).

\subsection{Analysis Applied to the Cakes}

\subsubsection{Mass and Volume}


The mass and volume measurements of the cake were measured using the rapeseed displacement method. The mass measurements in grams were determined right after the cake came out of the oven. Specific volume values were calculated according to the results gathered on mass and volume (AACC, Method 10-05.01).

\subsubsection{Determination of Baking Loss}

Determination of baking loss was calculated by the weight difference between uncooked doughs and cooked cakes.

\subsubsection{Ash Content}

Ash determination has been done in the ash oven (Magmatherm, MT 1105, Turkey) at $600{ }^{\circ} \mathrm{C}$ for 6 hours until it has a greyish color (AACC Method 08-01).

\subsubsection{Moisture Content}

Moisture analysis was performed by drying the cake samples in between around 105-135 oC in a drying oven (Memmert, UNB 400, Germany) until they were brought to constant weight. The samples were weighed before and after the drying process, and their moisture content was determined (AACC Method 44-19).

\subsubsection{Color Analysis}

The color determination of cake samples was conducted with a colorimeter device (Konica-Minolta, CR400, Japan). After the device's calibration, $L^{*}, a^{*}$, and $b^{*}$ values were recorded. According to the Hunter system used in color determination, $\mathrm{L}^{*}$ value shows the whiteness and blackness of the color while the a* value represents the transition from red to green, and the $b^{*}$ value is for the transition from yellow to blue (Salehi \& Kashaninejad, 2015).

\subsubsection{Textural Properties}

The textural properties of cake samples were determined using a Texture Analyzer (Brookfield texture Analyzer, USA) with a 20-mm diameter prob (20 $\mathrm{mm}$ height). Stiffness, deformation in stiffness, cohesive force, stickiness, fiber length, cohesiveness, flexibility, gumminess, chewiness parameters were examined (Ghaboos et al., 2018).

\subsection{Sensory Properties}

Sensory properties were measured using the hedonic scale by 10 experienced panelists. The cake samples were evaluated out of 6 in terms of appearance, texture, smell, taste while eating, taste after eating, and overall acceptance.

\subsection{Statistical Analysis}

Physical, chemical, and sensory characteristic data of samples in the study were evaluated with a one-way analysis of variance (one-way ANOVA) using the JMP Pro software package. The difference between significant averages resulting from the analysis was tested at a level of $\mathrm{p}<0.05$ via Tukey's multiple comparison test (Abdi and Williams, 2010).

Table 1. Flour composition of cakes

\begin{tabular}{ccccccccccc}
\hline Flour & BWF & CF & RF & CPF & QF & WF & M1 & M2 & M3 & M4 \\
\hline BWF & $100 \%$ & - & - & - & - & & $20 \%$ & $30 \%$ & $30 \%$ & $10 \%$ \\
CF & - & $100 \%$ & - & - & - & & $20 \%$ & $10 \%$ & $20 \%$ & $20 \%$ \\
RF & - & - & $100 \%$ & - & - & & $20 \%$ & $30 \%$ & $20 \%$ & $30 \%$ \\
CPF & - & - & - & $100 \%$ & - & & $20 \%$ & $10 \%$ & $10 \%$ & $10 \%$ \\
QF & - & - & - & - & $100 \%$ & & $20 \%$ & $20 \%$ & $20 \%$ & $30 \%$ \\
WF & - & - & - & - & - & $100 \%$ & & & & \\
\hline
\end{tabular}

BWF: buckwheat flour; CF: corn flour; RF: rice flour; CPF: chickpea flour; QF: quinoa flour; WF: wheat flour; M1: $\operatorname{mix} 1 ;$ M2: mix2; M3: mix3; M4: mix4

\section{Results and Discussion}

\subsection{Analyses Done on Dough Formulations}

\subsubsection{The Rheological Properties of Dough Formulations}

The viscoelastic properties of dough formulation samples were determined after oscillation measurement results. Storage $\left(G^{\prime}\right)$, loss $(G$ "), and complex viscosity $(\eta)$ values were identified as a function of angular velocity and were given in Figure 1. As seen in the results of viscoelastic measurements, storage modulus was found to be higher than loss modulus in all the samples. This was an indication that the elasticity was more dominant than the viscosity in all the samples. Besides, there was a noticeable decrease in the viscosity with the increasing angular velocity. This demonstrated that all the samples had the shear thinning property. It was concluded that the dough samples made with the BWF had the highest G'. G' values of the mixtures 1, 3, 4, and WF samples were quite alike, and the mixtures $1,3,4$, and the control samples showed similar rheological properties. The dough formulations with the high G' and G" values might most likely be costly since they would require a great deal of energy in kneading and shaping processes. 
Another parameter that informs us about dough processability is $\tan \delta$. This value is acquired with the ratio of the viscose module to the elastic one $\left(G^{\prime \prime} / G^{\prime}\right)$ and gives information about the relative elasticity of the material (Peyronel \& Campos, 2012). As seen in Figure 1, the RF sample had the lowest $\tan \delta$ value while the control dough formulation had the highest. A high tan delta value suggests that the sample is more prone to mechanical development. As it is understood from the results, the closest value to the control (WF) sample was the M1 sample.

Figure 1. Viscoelastic properties of cakes dough samples

\subsubsection{The Viscosity Parameters of the Dough}

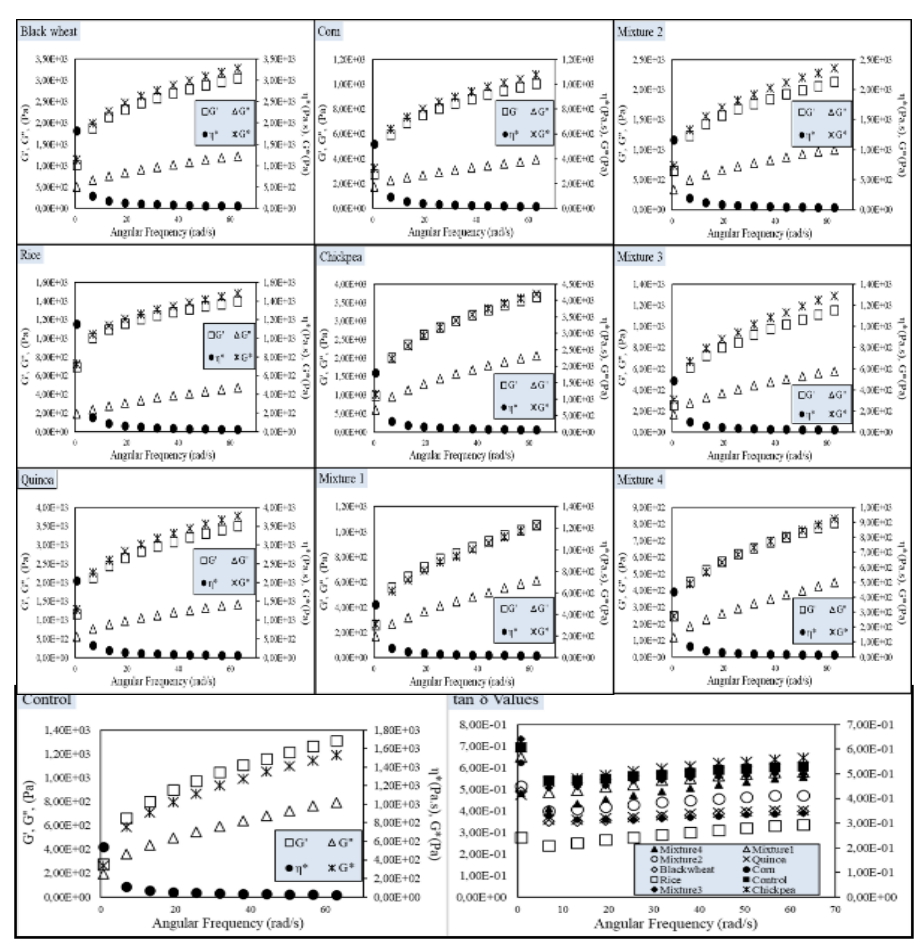

\section{Formulations}

The viscosity values were given in Figure 2 . In all the cake samples, the viscosity decreased between 1 to 5 minutes, whereas it was observed that it slightly increased between 5 to 10 minutes. In a study, Rahmati (2014) determined the viscosity value of cake samples made with wheat flour as $1,57 \mathrm{~g} / \mathrm{s}$.

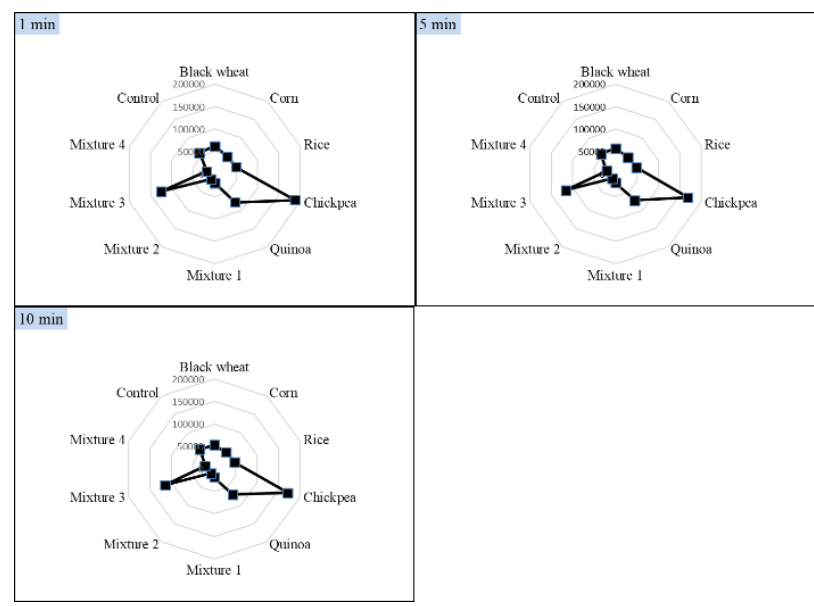

Figure 2. Viscosity analysis values

\subsubsection{Protein, Density, and pH Values of Doughs}

The results of the protein, density, and $\mathrm{pH}$ analyses are shown in Table 2 . The highest density rate was seen on the e-ISSN: 2148-2683
WF cake with 1,0506, while the lowest was in the RF cake mixture with 0,8912 . In a study, Malek (2013) determined the density level of a dough formulation made with the WF as $0.64-0.96 \mathrm{~g} / \mathrm{cm} 3$, whereas Yildız (2002) found it between $0.78-0.80 \mathrm{~g} / \mathrm{cm} 3$. Akbas (2009), on the other hand, indicated that it was $0.82-0.90 \mathrm{~g} / \mathrm{cm} 3$. It was seen that the results of our samples and the ones of the literature review had shown similarities along with very few differences. One reason for this difference was predicted to arise from the ratios of the raw material used and the dry matter of cakes. Regarding protein contents of samples, $\mathrm{CPF}$ was found to be the highest while CF was the lowest.

Table 2. Protein, density and $\mathrm{pH}$ value in cake dough

\begin{tabular}{cccc}
\hline Cake dough & Protein $(\%)$ & Density $\left(\mathrm{g} / \mathrm{cm}^{3}\right)$ & $\mathrm{pH}$ \\
\hline BWF & $13,76^{ \pm 0,0694}$ & $1,0287^{\mathrm{c}}$ & $6,2^{\text {cde }}$ \\
CF & $6,18^{ \pm 0,1223}$ & $1,0375^{\mathrm{b}}$ & $6,3^{\mathrm{bc}}$ \\
RF & $9,58^{ \pm 0,2132}$ & $0,8912^{\mathrm{h}}$ & $6,4^{\mathrm{ab}}$ \\
CPF & $24,73^{ \pm 0,3054}$ & $0,9834^{\mathrm{f}}$ & $6,2^{\mathrm{bcd}}$ \\
QF & $14,63^{ \pm 0,0619}$ & $0,9219^{\mathrm{g}}$ & $6,2^{\text {cde }}$ \\
M1 & 13,77 & $1,0171^{\mathrm{d}}$ & $6,4^{\mathrm{ab}}$ \\
M2 & 13,01 & $0,9938^{\mathrm{e}}$ & $6,1^{\mathrm{de}}$ \\
M3 & 12,67 & $1,0463^{\mathrm{a}}$ & $6,1^{\mathrm{e}}$ \\
M4 & 12,34 & $0,9275^{\mathrm{g}}$ & $6,1^{\mathrm{e}}$ \\
WF & $12,19^{ \pm 0,5871}$ & $1,0506^{\mathrm{a}}$ & $6,5^{\mathrm{a}}$ \\
\hline
\end{tabular}

BWF: buckwheat flour; $\mathrm{CF}$ : corn flour; RF: rice flour; CPF: chickpea flour; QF: quinoa flour; WF: wheat flour; M1: mix1; M2: $\operatorname{mix} 2$; M3: $\operatorname{mix} 3$; M4: $\operatorname{mix} 4$

\subsection{The Analyses Performed on Cake Samples}

\subsubsection{The determination of the amount of volume, weight, moisture, and ash on cake samples}

The cake analyses on volume, weight, moisture and ash content were given in Table 3. By percentage, the moisture ratio was the highest in the BWF cake with 25,19, whereas it was the lowest on the M3 cake. It was observed that the QF cake had the highest ash content value by percentage with 2,947 , while the lowest was the BWF cake with 2,179. This observed difference is thought to derive from the different mineral matter contents of flours used. Volumes were found to be between 32,7-39,3. The highest volume value belongs to the $\mathrm{CF}$.

Table 3. Cake volume, weight, moisture and ash values

\begin{tabular}{ccccc}
\hline Cake & $\begin{array}{c}\text { Volume } \\
(\mathrm{ml} / \mathrm{gr})\end{array}$ & $\begin{array}{c}\text { Weight } \\
(\mathrm{g})\end{array}$ & $\begin{array}{c}\text { Moisture } \\
(\%)\end{array}$ & $\begin{array}{c}\text { Ash } \\
(\%)\end{array}$ \\
\hline BWF & $38,35^{\mathrm{bc}}$ & $39,55^{\mathrm{ab}}$ & $25,19^{\mathrm{a}}$ & $2,179^{\mathrm{e}}$ \\
CF & $39,3^{\mathrm{a}}$ & $39,4^{\mathrm{b}}$ & $23,68^{\mathrm{c}}$ & $2,274^{\mathrm{de}}$ \\
RF & $36,55^{\mathrm{e}}$ & $37,8^{\mathrm{d}}$ & $24,84^{\mathrm{ab}}$ & $2,72^{\mathrm{b}}$ \\
CPF & $33^{\mathrm{g}}$ & $35,34^{\mathrm{g}}$ & $21,47^{\mathrm{e}}$ & $2,335^{\mathrm{d}}$ \\
QF & $38,2^{\mathrm{bc}}$ & $39,5^{\mathrm{ab}}$ & $23,15^{\mathrm{d}}$ & $2,947^{\mathrm{a}}$ \\
M1 & $37,9^{\mathrm{cd}}$ & $38,49^{\mathrm{c}}$ & $22,61^{\mathrm{d}}$ & $2,463^{\mathrm{c}}$ \\
M2 & $39,15^{\mathrm{b}}$ & $39,67^{\mathrm{a}}$ & $24,05^{\mathrm{bc}}$ & $2,716^{\mathrm{b}}$ \\
M3 & $32,7^{\mathrm{g}}$ & $36,9^{\mathrm{e}}$ & $21,02^{\mathrm{e}}$ & $2,695^{\mathrm{b}}$ \\
M4 & $37,65^{\mathrm{de}}$ & $38,6^{\mathrm{c}}$ & $23,83^{\mathrm{c}}$ & $2,416^{\mathrm{d}}$
\end{tabular}




\begin{tabular}{lllll} 
WF & $35,25^{\mathrm{f}}$ & $35,95^{\mathrm{f}}$ & $22,79^{\mathrm{d}}$ & $2,691^{\mathrm{b}}$ \\
\hline
\end{tabular}

BWF: buckwheat flour; CF: corn flour; RF: rice flour; CPF: chickpea flour; QF: quinoa flour; WF: wheat flour; M1: mix1; M2: $\operatorname{mix} 2 ; \mathrm{M} 3$ : $\operatorname{mix} 3$; M4: $\operatorname{mix} 4$

\subsubsection{The Baking Loss Values of the Cake Samples}

As shown in Table 4, after 1-hour rest, the highest loss was found in the CPF cake with $14,91 \%$, while the lowest was M2 with $2,17 \%$. The baking loss value of WF was the second, close to the highest.

Table 4. Cake cooked loss values (initial: $40 \mathrm{~g}$ )

\begin{tabular}{cccc}
\hline Cake & $\begin{array}{c}1 \text { hour rested cake } \\
\text { weight } \\
(\mathrm{g})\end{array}$ & $\begin{array}{c}\text { Loss of } \\
\text { cookware } \\
(\mathrm{g})\end{array}$ & $\begin{array}{c}\text { Loss of } \\
\text { cookware } \\
(\%)\end{array}$ \\
\hline BWF & $38,5^{\mathrm{bc}}$ & $1,5^{\mathrm{gh}}$ & $3,9^{\mathrm{h}}$ \\
CF & $38,2^{\mathrm{cd}}$ & $1,8^{\mathrm{g}}$ & $4,71^{\mathrm{g}}$ \\
RF & $36,6^{\mathrm{e}}$ & $3,4^{\mathrm{d}}$ & $9,29^{\mathrm{d}}$ \\
CPF & $34,81^{\mathrm{g}}$ & $5,19^{\mathrm{a}}$ & $14,91^{\mathrm{a}}$ \\
QF & $38,6^{\mathrm{ab}}$ & $1,4^{\mathrm{h}}$ & $3,63^{\mathrm{h}}$ \\
M1 & $37,95^{\mathrm{d}}$ & $2,05^{\mathrm{f}}$ & $5,4^{\mathrm{f}}$ \\
M2 & $39,15^{\mathrm{a}}$ & $0,85^{\mathrm{i}}$ & $2,17^{\mathrm{i}}$ \\
M3 & $36,2^{\mathrm{f}}$ & $3,8^{\mathrm{c}}$ & $10,5^{\mathrm{c}}$ \\
M4 & $37,55^{\mathrm{d}}$ & $2,45^{\mathrm{e}}$ & $6,52^{\mathrm{e}}$ \\
WF & $35,5^{\mathrm{f}}$ & $4,5^{\mathrm{b}}$ & $12,68^{\mathrm{b}}$ \\
\hline
\end{tabular}

BWF: buckwheat flour; CF: corn flour; RF: rice flour; CPF: chickpea flour; QF: quinoa flour; WF: wheat flour; M1: mix1; M2: mix2; M3: mix3; M4: $\operatorname{mix} 4$

\subsubsection{Color Values of Cake Samples}

The color analyses were given in Table 5 (Cake pictures were also given in figure 5). In Hunter $\mathrm{L} \mathrm{a} b$ System, the value $\mathrm{L}$ shows the brightness while $\mathrm{L}=0$ represents the blackness and $\mathrm{L}=100$, the whiteness. In addition, the values $+\mathrm{a},-\mathrm{a},+\mathrm{b}$, and $-\mathrm{b}$ correspond to the redness, the greenness, the yellowness, and the blueness, respectively. The inner color brightness of the cakes was found the brightest in the RF cake. Compared to the other cakes, the inner color of the BWF cake was more like red. The inner color of the WF cake, on the other hand, was rather more similar to the green than other cakes. While the yellowest cake was the $\mathrm{CF}$, the closest color to blue was on the BWF cake.

The highest brightness value of the exterior color was detected in the WF cake. The outside of the BWF cake was more reddish, and the WF cake was more greenish compared to other cake samples. The outside of the CF cake was the yellowest, while the M3 one was closer to blue. In a study, Malek (2013) revealed the following figures on cake formulations made with roasted wheat flour for outer color as L (Lightness-darkness): 53.69, +a (red): 15.82, +b(yellow) \%: 26.49; and for inner color as L:73.85, +a:1.64 and $+b: 19,83$. In a different study, Majzoobi et al. (2014) found the outer color values of the WF cake as L: 40.3, a: 9.7, b: 26.6, and the inner color values as L: 68.0, a: -4.7 , b: 42.0. When compared with our study, the WF cake sample had similar values. However, the outer color results of both studies differed a great deal, presumably owing to the formulations.

Table 5. Cake interior and cake crust color values

cake interior color cake crust color

\begin{tabular}{cllllll} 
Cake & $\mathrm{L}$ & $\mathrm{a}$ & $\mathrm{b}$ & $\mathrm{L}$ & $\mathrm{a}$ & $\mathrm{b}$ \\
\hline BWF & $53,68^{ \pm 0,8700}$ & $3,95^{ \pm 0,0800}$ & $21,04^{ \pm 0,0500}$ & $52,45^{ \pm, 8488}$ & $12,66^{ \pm 1,4076}$ & $36,80^{ \pm 0,9385}$ \\
CF & $71,38^{ \pm 0,3850}$ & $-1,58^{ \pm 0,1300}$ & $45,23^{ \pm 0,6650}$ & $69,15^{ \pm 0,6093}$ & $5,88^{ \pm 1,9069}$ & $54,84^{ \pm 0,6574}$ \\
RF & $77,49^{ \pm 0,4100}$ & $-2,18^{ \pm 0,650}$ & $32,07^{ \pm 0,0200}$ & $66,16^{ \pm 2,9559}$ & $10,87^{ \pm 2,8778}$ & $49,26^{ \pm 1,8077}$ \\
CPF & $69,98^{ \pm 0,6150}$ & $0,47^{ \pm 0,1150}$ & $41,07^{ \pm 0,2150}$ & $73,68^{ \pm 1,6251}$ & $5,79^{ \pm 1,6580}$ & $42,82^{ \pm 0,8448}$ \\
QF & $61,01^{ \pm 0,8100}$ & $2,09^{ \pm 0,1050}$ & $30,65^{ \pm 0,1550}$ & $62,53^{ \pm 1,6795}$ & $6,91^{ \pm 1,1721}$ & $38,61^{ \pm 0,8535}$ \\
M1 & $69,35^{ \pm 1,2750}$ & $1,00^{ \pm 0,2800}$ & $34,76^{ \pm 1,3550}$ & $65,33^{ \pm 1,5030}$ & $7,73^{ \pm 1,2973}$ & $45,07^{ \pm 1,8336}$ \\
M2 & $65,41^{ \pm 1,7500}$ & $1,80^{ \pm 0,3700}$ & $28,41^{ \pm 1,0700}$ & $62,40^{ \pm 0,6468}$ & $8,67^{ \pm 1,1836}$ & $40,50^{ \pm 1,0249}$ \\
M3 & $64,73^{ \pm 1,2500}$ & $2,40^{ \pm 0,2400}$ & $24,68^{ \pm 0,2150}$ & $74,23^{ \pm 0,2872}$ & $3,06^{ \pm 0,5586}$ & $29,92^{ \pm 0,7537}$ \\
M4 & $68,15^{ \pm 3,7950}$ & $0,64^{ \pm 0,5100}$ & $31,82^{ \pm 0,4550}$ & $63,49^{ \pm 0,3800}$ & $8,90^{ \pm 0,2551}$ & $43,47^{ \pm 0,8475}$ \\
WF & $78,83^{ \pm 0,8590}$ & $-2,38^{ \pm 1,2394}$ & $29,58^{ \pm 0,2301}$ & $80,95^{ \pm 1,1067}$ & $1,88^{ \pm 0,5756}$ & $39,29^{ \pm 0,3981}$ \\
\hline
\end{tabular}

BWF: buckwheat flour; CF: corn flour; RF: rice flour; CPF: chickpea flour; QF: quinoa flour; WF: wheat flour; M1: mix1; M2: mix2; M3: mix3; M4: $\operatorname{mix} 4$

\subsubsection{Textural Properties}

The texture analysis values of cake samples are given in Table 6 .

The highest values were obtained from the BWF cake regarding elasticity and chewiness in the DEF 50 test, respectively $9,75 \mathrm{~mm}$ and $65,20 \mathrm{~mJ}$. The RF cake also had the highest values for deformation in stiffness as $12,32 \mathrm{~mm}$ and cohesiveness as 0,4 . In contrast, the M1 cake had the highest cohesive force and stickiness values of $19 \mathrm{~g}, 0,30 \mathrm{~mJ}$, and 0,18 $\mathrm{mJ}$, respectively. While mixture 3 was the highest in fiber length as 3,04 $\mathrm{mm}$, it was confirmed that the stiffness in the M4 cake was the highest as $1763 \mathrm{~g}$.

In the freshness, the elasticity in the BWF cake was the highest, with $8,23 \mathrm{~mm}$. The cohesiveness was found to be the highest in the RF cake as 0,51. The WF cake was also the highest in terms of stiffness, cohesive force, stickiness, gumminess, and chewiness, and the values were as follows respectively: $3244.5 \mathrm{~g}, 19 \mathrm{~g}, 0.52 \mathrm{~mJ}, 0.07 \mathrm{~mJ}, 1015.2 \mathrm{~g}$, and $75.56 \mathrm{~mJ}$. The fiber length of the M3 cake was highest with a value of $6,56 \mathrm{~mm}$, and the deformation in stiffness values of BWF, CF, RF, and M4 cake samples was high as 10,00 mm. In a study of Majzoobi et al. (2014) the stiffness, cohesiveness, elasticity, and chewiness values were $0,430 \mathrm{~kg}, 0,073 \mathrm{~g} \mathrm{~s}-1$, $0,860,0,958$ and $0,305 \mathrm{~kg}$ respectively. On the other hand, it was seen in a study by Yildiz (2010) that the values of a cake made with wheat flour ranged from 298.85-628.68 g for stiffness, 0,442-0,580 for stickiness, and 129,695-310.089 for chewiness. It was similarly observed that the gluten-free RF cake values were between $350,5-1819,9 \mathrm{~g}$ in stiffness, $128.961-806.264$ in chewiness, and $0.397-0.563$ in stickiness. Lastly, the values of gluten-free cakes made the $\mathrm{CF}$ and potato starch differ between 376,3-1093,0 for stiffness, 0.378-0.595 for stickiness, and 134.267-469.680 for chewiness.

\subsubsection{Sensory Analyses of the Cake Samples}

Sensory results of the cakes were shown in Figure 3. Out of all the cake samples, the CF cake had the highest points with 31 in terms of appearance. While other cakes have been liked moderately, the BWF cake, with 13 points, and the QF cake, with 17 points, were the least liked in terms of appearance. The WF and CF cakes were the most acclaimed ones with 28 points in terms of texture. When all the samples were evaluated regarding their smell, the WF cake, 28 points, the CF cake, 27 points, and the RF cake, 27 points, distinguished themselves and got the most likes. The M4 sample had the worst smell with 9 points, while the rest were regarded as moderate. As for their taste, while eating, the CF and WF cakes were the most 
preferred ones with 29 points, whereas the M4 cake was the least with 3 points. The QF and M3 samples were not acclaimed with 9 points, and the rest was seen as moderate. The most liked cake on taste after eating test was found to be the CF cake with 30 points. The M4 cake, however, was the last one with 4 points, and the rest of the samples were regarded as average. The BWF, 9 points, the QF, 8 points, and the M3, 7 points, cakes were considered the least favorable ones. For overall liking, the $\mathrm{CF}$ and controlling WF cakes with 27 points along with the RF cake with 25 points were the most liked ones, whereas the M4, 10 points, the M3, 9 points, and the QF, 5 points, cakes were regarded as the least favorable by the panelists. The sensory evaluation has crucial importance since it reflects consumers' general admirations and wishes about product quality.

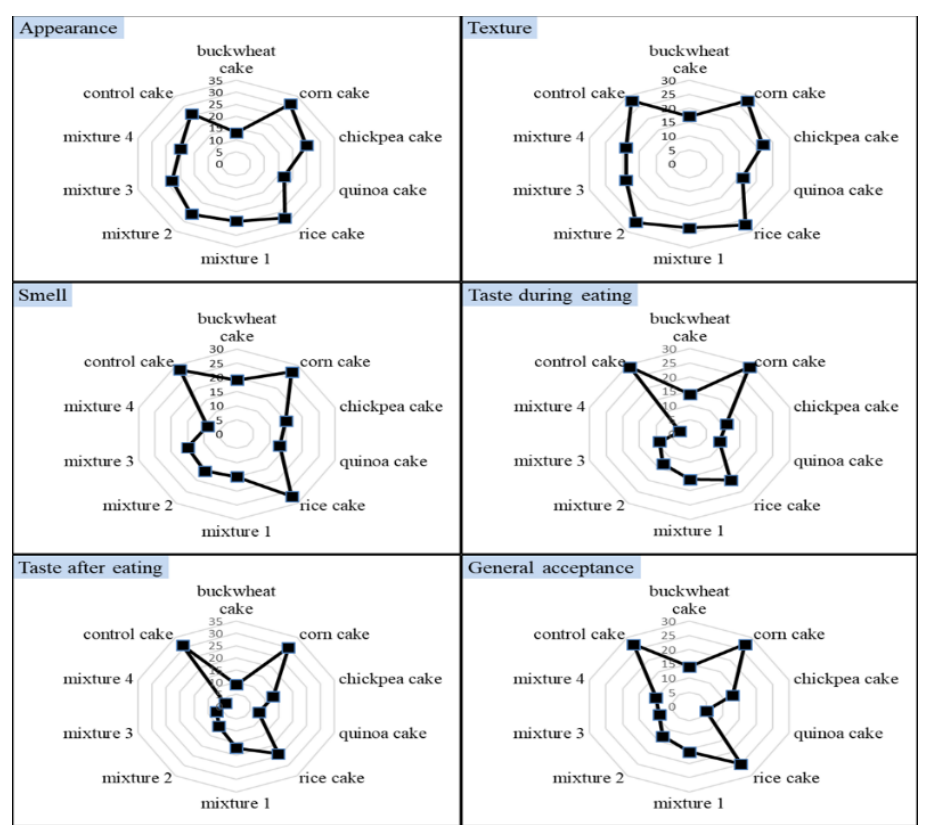

Figure 3. Sensory Properties of cakes 
Table 6. Texture analysis values

\begin{tabular}{|c|c|c|c|c|c|c|c|c|c|}
\hline Cake-DEF50 & $\begin{array}{l}\begin{array}{l}\text { Hardness } \\
(\mathrm{g})\end{array} \\
\end{array}$ & $\begin{array}{l}\text { Hardness deformation } \\
(\mathrm{mm})\end{array}$ & Cohesive force (g) & $\begin{array}{l}\text { Adhesiveness } \\
(\mathrm{mJ})\end{array}$ & $\begin{array}{l}\text { Fiber length } \\
\quad(\mathrm{mm})\end{array}$ & Cohesiveness & $\begin{array}{l}\text { Elasticity } \\
(\mathrm{mm})\end{array}$ & $\begin{array}{c}\text { Gumminess } \\
(\mathrm{g})\end{array}$ & $\begin{array}{l}\text { Chewiness } \\
(\mathrm{mJ}\end{array}$ \\
\hline BWF & $1683^{c}$ & $12,28^{\mathrm{a}}$ & $11,5^{\mathrm{b}}$ & $0,12^{\mathrm{b}}$ & $1,01^{\mathrm{d}}$ & $0,41^{\mathrm{a}}$ & $9,75^{\mathrm{a}}$ & $681,9^{\mathrm{b}}$ & $65,2^{\mathrm{a}}$ \\
\hline $\mathrm{CF}$ & $1023,5^{\mathrm{h}}$ & $12,3^{\mathrm{a}}$ & $6^{\mathrm{e}}$ & $0,06^{\mathrm{cd}}$ & $2,02^{\mathrm{b}}$ & $0,23^{\mathrm{d}}$ & $8,32^{\mathrm{e}}$ & $230,5^{\mathrm{g}}$ & $18,81^{\mathrm{e}}$ \\
\hline $\mathrm{RF}$ & $1041^{\mathrm{g}}$ & $12,32^{\mathrm{a}}$ & $8,5^{\mathrm{d}}$ & $0,08^{\mathrm{bc}}$ & $0,75^{\mathrm{e}}$ & $0,43^{\mathrm{a}}$ & $9,42^{\mathrm{b}}$ & $449,5^{\mathrm{d}}$ & $41,53^{\mathrm{c}}$ \\
\hline $\mathrm{CPF}$ & $1520,5^{\mathrm{f}}$ & $11,53^{\mathrm{b}}$ & $1,5^{\mathrm{g}}$ & $0^{\mathrm{e}}$ & $0,25^{\mathrm{g}}$ & $0,15^{\mathrm{e}}$ & $5,71^{\mathrm{h}}$ & $228,3^{\mathrm{h}}$ & $12,78^{\mathrm{g}}$ \\
\hline $\mathrm{QF}$ & $926,5^{\mathrm{i}}$ & $12,32^{\mathrm{a}}$ & $9,5^{\mathrm{c}}$ & $0,12^{\mathrm{b}}$ & $0,75^{\mathrm{e}}$ & $0,26^{\mathrm{cd}}$ & $6,87^{\mathrm{g}}$ & $238,2^{\mathrm{f}}$ & $16,05^{\mathrm{f}}$ \\
\hline M1 & $1627,5^{\mathrm{d}}$ & $12,29^{\mathrm{a}}$ & $19^{\mathrm{a}}$ & $0,3^{\mathrm{a}}$ & $1,77^{\mathrm{c}}$ & $0,33^{\mathrm{bc}}$ & $8,82^{\mathrm{cd}}$ & $529,9^{\mathrm{c}}$ & $45,84^{\mathrm{b}}$ \\
\hline M2 & $644^{j}$ & $11,56^{\mathrm{b}}$ & $1,5^{\mathrm{g}}$ & $0,01^{\mathrm{de}}$ & $0,25^{\mathrm{g}}$ & $0,34^{\mathrm{b}}$ & $8,53^{\mathrm{d}}$ & $221,7^{\mathrm{i}}$ & $18,54^{\mathrm{e}}$ \\
\hline M3 & $1586,5^{\mathrm{e}}$ & $5,23^{\mathrm{a}}$ & $1,5^{\mathrm{g}}$ & $0^{\mathrm{e}}$ & $3,04^{\mathrm{a}}$ & $0,07^{\mathrm{f}}$ & $3,05^{\mathrm{i}}$ & $108,5^{\mathrm{j}}$ & $3,25^{\mathrm{h}}$ \\
\hline M4 & $1763^{\mathrm{a}}$ & $12,29^{\mathrm{a}}$ & $3,5^{\mathrm{f}}$ & $0,02^{\text {cde }}$ & $0,51^{\mathrm{f}}$ & $0,4^{\mathrm{a}}$ & $9,33^{\mathrm{bc}}$ & $706,9^{\mathrm{a}}$ & $64,68^{\mathrm{a}}$ \\
\hline WF & $1745,5^{\mathrm{b}}$ & $12,29^{\mathrm{a}}$ & $2,5^{\mathrm{f}}$ & $0,02^{\text {cde }}$ & $0,25^{\mathrm{g}}$ & $0,25^{\mathrm{cd}}$ & $7,36^{\mathrm{f}}$ & $443,8^{\mathrm{e}}$ & $32,03^{\mathrm{d}}$ \\
\hline $\begin{array}{c}\text { Cake- } \\
\text { FRESHNESS }\end{array}$ & $\begin{array}{l}\text { Hardness } \\
(\mathrm{g})\end{array}$ & $\begin{array}{l}\text { Hardness deformation } \\
(\mathrm{mm})\end{array}$ & Cohesive force (g) & $\begin{array}{c}\text { Adhesiveness } \\
(\mathrm{mJ})\end{array}$ & $\begin{array}{l}\text { Fiber length } \\
(\mathrm{mm})\end{array}$ & Cohesiveness & $\begin{array}{c}\text { Elasticity } \\
(\mathrm{mm})\end{array}$ & $\begin{array}{c}\text { Gumminess } \\
(\mathrm{g})\end{array}$ & $\begin{array}{c}\text { Chewiness } \\
(\mathrm{mJ})\end{array}$ \\
\hline BWF & $1204^{\mathrm{g}}$ & $10^{\mathrm{a}}$ & $4,5^{\mathrm{e}}$ & $0,02^{\mathrm{d}}$ & $0,5^{\mathrm{d}}$ & $0,48^{\mathrm{a}}$ & $8,23^{\mathrm{a}}$ & $583,9^{\mathrm{d}}$ & $47,12^{\mathrm{c}}$ \\
\hline $\mathrm{CF}$ & $1550^{\mathrm{e}}$ & $10^{\mathrm{a}}$ & $3,5^{\mathrm{f}}$ & $0,02^{\mathrm{d}}$ & $0^{\mathrm{e}}$ & $0,33^{\mathrm{de}}$ & $7,16^{\mathrm{d}}$ & $504,8^{\mathrm{e}}$ & $35,44^{\mathrm{e}}$ \\
\hline $\mathrm{RF}$ & $877,5^{\mathrm{i}}$ & $10^{\mathrm{a}}$ & $4,5^{\mathrm{e}}$ & $0,02^{\mathrm{d}}$ & $0^{\mathrm{e}}$ & $0,51^{\mathrm{a}}$ & $7,76^{\mathrm{b}}$ & $446^{\mathrm{g}}$ & $33,94^{\mathrm{f}}$ \\
\hline $\mathrm{CPF}$ & $2028^{c}$ & $9,98^{\mathrm{a}}$ & $2^{\mathrm{gh}}$ & $0,03^{\text {cd }}$ & $5,55^{\mathrm{b}}$ & $0,21^{\text {ef }}$ & $5,64^{\mathrm{f}}$ & $429,8^{\mathrm{i}}$ & $23,77^{\mathrm{g}}$ \\
\hline $\mathrm{QF}$ & $3244,5^{\mathrm{a}}$ & $9,94^{\mathrm{a}}$ & $19^{\mathrm{a}}$ & $0,52^{\mathrm{a}}$ & $0,5^{\mathrm{d}}$ & $0,31^{\mathrm{cd}}$ & $7,59^{\mathrm{c}}$ & $1015,2^{\mathrm{a}}$ & $75,56^{\mathrm{a}}$ \\
\hline M1 & $1252^{\mathrm{f}}$ & $9,99^{\mathrm{a}}$ & $16^{\mathrm{b}}$ & $0,1^{\mathrm{b}}$ & $0,5^{\mathrm{d}}$ & $0,47^{\mathrm{ab}}$ & $7,81^{\mathrm{b}}$ & $585,8^{\mathrm{c}}$ & $44,87^{\mathrm{d}}$ \\
\hline M2 & $948^{\mathrm{h}}$ & $9,52^{\mathrm{b}}$ & $6,5^{\mathrm{c}}$ & $0,02^{\mathrm{d}}$ & $0,5^{\mathrm{d}}$ & $0,47^{\mathrm{ab}}$ & $7,55^{\mathrm{c}}$ & $441,7^{\mathrm{h}}$ & $32,7^{\mathrm{f}}$ \\
\hline M3 & $3039,5^{\mathrm{b}}$ & $7,43^{\mathrm{c}}$ & $2,5^{\mathrm{g}}$ & $0,03^{\mathrm{bcd}}$ & $6,56^{\mathrm{a}}$ & $0,15^{\mathrm{f}}$ & $4,3^{\mathrm{g}}$ & $469,2^{\text {f }}$ & $19,79^{\mathrm{h}}$ \\
\hline M4 & $1589^{\mathrm{d}}$ & $10^{\mathrm{a}}$ & $5,5^{\mathrm{d}}$ & $0,09^{\mathrm{bc}}$ & $0,51^{\mathrm{d}}$ & $0,49^{\mathrm{a}}$ & $7,82^{\mathrm{b}}$ & $775,7^{\mathrm{b}}$ & $59,49^{\mathrm{b}}$ \\
\hline WF & $710,5^{\mathrm{j}}$ & $9,53^{\mathrm{ab}}$ & $1,5^{\mathrm{h}}$ & $0,01^{\mathrm{d}}$ & $5,04^{\mathrm{c}}$ & $0,38^{\mathrm{bc}}$ & $6,76^{\mathrm{e}}$ & $267,4^{\mathrm{i}}$ & $17,72^{\mathrm{i}}$ \\
\hline
\end{tabular}

BWF: buckwheat flour; CF: corn flour; RF: rice flour; CPF: chickpea flour; QF: quinoa flour; WF: wheat flour; M1: mix 1; M2: mix2; M3: mix3; M4: mix4 


\section{Conclusions and Recommendations}

Celiac disease is an ailment common in Turkey as it is all around the world. The diet of the patients is crucial, and the consumption of products with gluten should be forbidden entirely. The presence of products with gluten is relatively high because of the common usage of wheat flour in the food industry, while gluten-free products are limited and over-costing. The purpose of this study was to manufacture new and lowercosting products for celiac patients. For this purpose, gluten-free cakes were prepared by using nutritious and gluten-free flours. After all the tests, it was observed that the physical, chemical, rheological, and textural analysis values of samples from our formulations bore a resemblance to the results of cake formulations made with wheat flour (control). In sensory analyses of the cake formulations, cake with cornflour got the highest preference, followed by rice flour cake and cake mixture 1. It was concluded that alternative products could be produced with the formulations above for celiac patients. Nonetheless, it was thought that products with aromatic admixtures might be preferred and consumed more in terms of sensory.

\section{Acknowledge}

This project was carried out within the scope of the TUBITAK 2209B / 2241A Industrial Focused Undergraduate Thesis Support Program. Project ID: 1139B411503248.

\section{References}

AACC (1999) Method 08-01.01. Ash -- Basic Method. Approved Methods of Analysis, 11th edition. St. Paul, MN: AACC International.

AACC (1999) Method 44-19.01. Moisture -- Air-Oven Method, Drying at $135^{\circ}$. Basic Method. Approved Methods of Analysis, 11th edition. St. Paul, MN: AACC International.

AACC (2000) Method 10-05.01. Guidelines for measurement of volume by rapeseed displacement. Approved Methods of Analysis, 11th edition. St. Paul, MN: AACC International.

Abdi, H., \& Williams, L. J. (2010). Tukey's honestly significant difference (HSD) test. Encyclopedia of Research Design. Thousand Oaks, CA: Sage, 1-5.

Akbaş, Ö. (2009). Usage of Exopolysaccharides in Cake Production (Kek Üretiminde Ekzopolisakkaritlerin Kullanım1). Master Thesis. Institute of Science. Van.

AOAC (2000). Method 992.23, In "Official Methods of Analysis", 17th Ed., AOAC International, Gaithersburg, MD.

Arslan, M., Rakha, A., Xiaobo, Z., \& Mahmood, M. A. (2019). Complimenting gluten free bakery products with dietary fiber: Opportunities and constraints. Trends in food science \& technology, 83, 194-202.

Bourekoua, H., Benatallah, L., Zidoune, M. N., \& Rosell, C. M. (2016). Developing gluten free bakery improvers by hydrothermal treatment of rice and corn flours. LWT, 73, 342-350.

Caio, G., Volta, U., Sapone, A., Leffler, D. A., De Giorgio, R., Catassi, C., \& Fasano, A. (2019). Celiac disease: a comprehensive current review. BMC medicine, 17(1), 1-20.

Ghaboos, H. S., Ardabili, S. S., \& Kashaninejad, M. (2018). Physico-chemical, textural and sensory evaluation of sponge cake supplemented with pumpkin flour. International Food Research Journal, 25(2), 854-860.
Macho, V. M. P., de Barros Menéres, M. C. A., e Silva, D. M. V., $\&$ de Andrade, D. J. C. (2020). The difference in symmetry of the enamel defects in celiac disease versus non-celiac pediatric population. Journal of Dental Sciences, 15(3), 345350.

Majzoobi, M., Hedayati, S., Habibi, M., Ghiasi, F., \& Farahnaky, A. (2014). Effects of corn resistant starch on the physicochemical properties of cake. Journal of Agricultural Science and Technology, 16(3), 569-576.

Moreno, M. D. L., Comino, I., \& Sousa, C. (2014). Alternative grains as potential raw material for gluten-free food development in the diet of celiac and gluten-sensitive patients. Austin J Nutri Food Sci, 2(3), 1016.

Norouzbeigi, S., Vahid-Dastjerdi, L., Yekta, R., Sohrabvandi, S., Zendeboodi, F., \& Mortazavian, A. M. (2020). Celiac therapy by administration of probiotics in food products: a review. Current Opinion in Food Science, 32, 58-66.

Palabiyik, I., Yildiz, O., Toker, O. S., Cavus, M., Ceylan, M. M., \& Yurt, B. (2016). Investigating the addition of enzymes in gluten-free flours-The effect on pasting and textural properties. LWT-Food Science and Technology, 69, 633-641.

Pehlivanoglu, H., Ozulku, G., Yildirim, R. M., Demirci, M., Toker, O. S., \& Sagdic, O. (2018). Investigating the usage of unsaturated fatty acid-rich and low-calorie oleogels as a shortening mimetic in cake. Journal of food processing and preservation, 42(6), e13621.

Peyronel, F., \& Campos, R. (2012). Methods used in the study of the physical properties of fats. In A. G. Marangoni (Ed.), Structure-function analysis of edible fats (pp. 262-277). Urbana: AOCS Press.

Radlović, N. (2013). Celiac disease. Srpski arhiv za celokupno lekarstvo, 141(1-2), 122-126.

Rahmati, N. F., \& Tehrani, M. M. (2014). Influence of different emulsifiers on characteristics of eggless cake containing soy milk: Modeling of physical and sensory properties by mixture experimental design. Journal of food science and technology, 51(9), 1697-1710.

Rao MA, Cooley HJ (1992). Rheological behavior of tomato pastes in steady and dynamic shear. J Texture Stud., 23, 415425.

Sakiyan, O., Sumnu, G., Sahin, S., Meda, V., Koksel, H., \& Chang, P. (2011). A study on degree of starch gelatinization in cakes baked in three different ovens. Food and Bioprocess Technology, 4(7), 1237-1244.

Salehi, F., \& Kashaninejad, M. (2015). Effect of drying methods on rheological and textural properties, and color changes of wild sage seed gum. Journal of food science and technology, 52(11), 7361-7368.

Tang, Y., Yang, Y., Wang, Q., Tang, Y., Li, F., Zhao, J., ... \& Ming, J. (2019). Combined effect of carboxymethylcellulose and salt on structural properties of wheat gluten proteins. Food Hydrocolloids, 97, 105189.

Yıldız, Ö. (2002). An Investigation on Low-Caloire Cakes (Düşük Kalorili Kek Üretimi Üzerine Bir Araştırma). Master Thesis. Institute of Science. Van.

Yıld1z, Ö. (2010). Investigation of the effects of different formulation, cooking and storage times on the gluten free cakes (Farklı formülasyon, pişirme ve depolama sürelerinin glutensiz kek kalitesi üzerine etkilerinin araştırılması) Doctorate thesis. Institute of Science. Van.

Yildiz, Ö., Toker, O. S., Yüksel, F., Cavus, M., Ceylan, M. M., \& Yurt, B. (2017). Pasting properties of buckwheat, rice and maize flours and textural properties of their gels: effect of 
ascorbic acid concentration. Quality Assurance and Safety of Crops \& Foods, 9(3), 313-321.

Yoo B, Rao MA (1996). A creep and dynamic rheological behavior of tomato concentrates: effect of concentration and finisher screen size. Journal of Texture Studies, 27, 451-459. http://dx.doi.org/10.1111/j.1745-4603.1996.tb00087. 